Jurnal Kejuruteraan SI 1(4) 2018: 7-14

http://dx.doi.org/10.17576/jkukm-2018-si1(4)-02

\title{
High Yield of Butanol Production in Repeated Batch Culture Fermentation by Clostridium Acetobutylicum YM1
}

(Penghasilan Tinggi Butanol dalam Fermentasi Kultur Sesekumpul Ulangan oleh Clostridium Acetobutylicum YM1)

\author{
Khadeja Khalifa Khalifa ${ }^{a}$, Abdualati Ibrahim Al-Tabib ${ }^{a}$, Mohd Sahaid Kalil ${ }^{\text {a,b,* }}$ \\ ${ }^{a}$ Research Centre for Sustainable Process Technology, \\ ${ }^{b}$ Chemical Engineering Programme, \\ Faculty of Engineering \& Built Environment, Universiti Kebangsaan Malaysia
}

Najeeb Kaid Nasser Al-Shorgani $\mathrm{i}^{\mathrm{a}, \mathrm{c}}$

${ }^{c}$ Department of Applied Microbiology, Faculty of Applied Sciences,

Taiz University, Taiz, Yemen

ABSTRACT

Butanol is the most promising alternative liquid biofuel that can substitute gasoline due to its properties which is more similar to gasoline than ethanol. In this study, butanol was produced by batch culture and repeated batch culture in acetone-butanol-ethanol fermentation (ABE) using a local strain of Clostridium acetobutylicum YM1. In batch culture using tryptone-yeast extract-acetate medium (TYA) containing $30 \mathrm{~g} / \mathrm{L}$ glucose, the maximum butanol concentration was $3.78 \mathrm{~g} / \mathrm{L}$ with a maximum butanol productivity of $0.08 \mathrm{~g} / \mathrm{L}$.h and the butanol yield was $0.15 \mathrm{~g} / \mathrm{g}$. Effect of some factors on the butanol production during repeated batch fermentation including drain and fill volume of medium and drain and fill time were investigated. The results of repeated batch fermentation showed that $50 \%(\mathrm{v} / \mathrm{v})$ of drain and fill volume at $48 \mathrm{~h}$ maximized the production of butanol, productivity and yield. The highest butanol concentration was $5.12 \mathrm{~g} / \mathrm{L}$ in the first cycle of repeated batch with a butanol productivity of $0.11 \mathrm{~g} / \mathrm{L}$.h and a butanol yield of $0.44 \mathrm{~g} / \mathrm{g}$. Repeated batch fermentation using free cells of Clostridium acetobutylicum YM1 eliminated the lag phase and then improved the productivity of butanol and total ABE. This study showed that repeated batch fermentation improved the efficiency of butanol production over batch culture fermentation by Clostridium acetobutylicum YM1.

Keywords: Repeated batch fermentation; Clostridium acetobutylicum YM1; Butanol; Biofuel

ABSTRAK

Butanol merupakan alternatif terbaik biofuel cecair sebagai gantian kepada gasolin. Dalam kajian ini, butanol telah dihasilkan secara fermentasi aseton-butanol-etanol (ABE) sesekumpul dan sesekumpul ulangan menggunakan strain tempatan Clostridium acetobutylicum YM1. Dalam kultur sesekumpul, kepekatan maksimum butanol adalah 3.78 g/L dengan produktiviti maksimum butanol $0.08 \mathrm{~g} / \mathrm{L} / \mathrm{j}$ dan hasil butanol $0.15 \mathrm{~g} / \mathrm{g}$. Kesan beberapa faktor terhadap penghasilan butanol dalam fermentasi sesekumpul ulangan termasuk isi padu serta masa pengambilan medium kultur dan penambahan medium segar telah dikaji. Keputusan menunjukkan $50 \%(\mathrm{v} / \mathrm{v})$ pengambilan medium kultur dan penambahan medium segar pada $48 \mathrm{j}$ memberikan hasil dan produktiviti yang maksimum. Kepekatan butanol tertinggi adalah $5.12 \mathrm{~g} / \mathrm{L}$ dalam kultur sesekumpul ulangan dengan produktiviti $0.11 \mathrm{~g} / \mathrm{L} / \mathrm{j}$ dan hasil $0.44 \mathrm{~g} / \mathrm{g}$. Kajian ini menunjukkan fermentasi sesekumpul ulangan berjaya memperbaiki serta meningkatkan penghasilan butanol dalam fermentasi sesekumpul Clostridium acetobutylicum YM1.

Kata kunci: Fermentasi sesekumpul ulangan; Clostridium acetobutylicum YM1; Butanol; Biofuel

\section{INTRODUCTION}

Butanol is considered as a potential renewable energy source that may in the upcoming years be utilized as a biofuel on a large scale instead of gasoline. Compared with ethanol, it possesses a number of valuable characteristics as a fuel, such as high-energy output, greater resistance towards temperature fluctuations, low damage potential and compatibility with the current internal combustion engine models (Al-Shorgani et al. 2016). Butanol can be generated in nature using some strains of Clostridium bacteria in a well-documented process known as acetone-butanol-ethanol (ABE) fermentation. Unfortunately, this process is lacking in terms of efficiency and is associated with a rather low yield due to the toxic nature of butanol. Research has been focusing on butanol lately as a key energy source and a renewable biofuel for the following reasons: the impending shortage of fossil fuels, the need for increased vitality and the rise in oil prices worldwide (Lee et al. 2008). Butanol has a large number of advantageous properties as a biofuel.

A major challenge that Clostridium-based ABE fermentation faces is butanol toxicity. The growth of the 
microorganisms and biofuel generation cease altogether if the medium has as little as $13-15 \mathrm{~g} / \mathrm{L}$ of butanol. This down regulatory mechanism of Clostridium was shown to be responsible for significantly diminished output past $15 \mathrm{~g} / \mathrm{L}$ of butanol fixation (Al-Shorgani et al. 2011; Chen et al. 2012).

There are several shortcomings in batch fermentation processes: the period required for bioreactor sterilization, during which operations are halted, considerable down time, long slack stage, low dissolvable restraint and low output. Nevertheless, these conventional processes are still in use in many fields. Different methodologies and procedures have been proposed for the production of butanol using low-cost feedstock, like Jerusalem artichokes, cheese whey, apple pomace, algae sulfites and rejected liquors.

Butanol may be produced by continuous fermentation and this allows for periodic elimination of toxic molecules throughout the operation. The introduction of fresh medium and the elimination of fermentation products is a useful technique to keep the process going at a steady rate and associated with significantly greater butanol yields. Due to physiological limitations pertaining to Clostridium species, large-scale butanol production presents many obstacles. Elevated butanol concentrations caused the bacteria to enter into a stationary phase in which spores are formed and the cells become unable to generate more butanol. In immobilized cell reactors, greater cell aggregation and stacking was found to allow microorganisms to tolerate greater quantities of the end products. Consequently, cell immobilization techniques were integrated into fermentation operations to generate higher profits.

Repeated-batch fermentation is considered as superior to conventional batch fermentation protocols for a number of reasons such as, it does not necessitate a new inoculum for every batch and is more suitable for long-term operations (Xu 2014). Moreover, cleaning and sterilization time is significantly lower with repeated batch fermentation; and, unlike continuous models, the method allows effortless control of the operation. However, in ethanol production using repeated-batch fermentation that employ free Saccharomyces cerevisiae cells, quantities of the fermented broth have to be removed regularly with the residual amount being used as an inoculum for the subsequent batch. Unfortunately, this has been known to result in significantly lower yeast loads, leading to decreased ethanol production in the following batches (Nuanpeng et al. 2011; Ariyajarearnwong et al. 2011). To prevent this from happening, a repeated-batch protocol with stationary fungal cells was suggested. Cell immobilization systems may reduce extraction costs, and compared with free cell fermentation procedures, they are associated with greater microorganism concentrations, faster fermentation, effortless cell recycle and lower possibility of product inhibition.

Using a systematic approach, a large number of mutant Clostridium strains have been engineered recently to enhance the yield of the solvent. Resilient solvent-producing strains were identified and metabolically scrutinized to evaluate their survival rate in butanol-rich media. Previously, simultaneous recuperation procedures were believed to be the only option to deal with solvent toxicity during fermentation (Qureshi \& Blaschek 2000). Procedures of the sort comprised a variety of evaporation, gas stripping, adsorption, and liquid-liquid extraction and osmosis techniques.

C. acetobutylicum, C. beijerinckii, C. saccharoperbutylacetonicum and C. sacharobutylicum are obligate anaerobes belonging to the Clostridium bacteria genus. These microorganisms are unable to grow in normal atmospheric conditions as they lack the cellular systems responsible for the elimination of active oxygen species, like superoxide anions and hydrogen peroxide. Consequently, these bacterial species have been shown to be highly vulnerable to the toxic effects of oxygen and unable to sustain their cellular integrity in aerobic conditions (Pfromm et al. 2010). The use of solvent-producing Clostridium for butanol production on a large scale may be troublesome considering the difficulty of achieving the necessary strict anaerobic conditions. The presence of oxygen during ABE fermentation processes has been shown to be detrimental (Yazdani \& Gonzalez 2007). Hence, it seems that substantial advancements in the field of bioenergy may not be possible without the identification of useful microorganisms that possess advantageous and novel characteristics (Bramono et al. 2011; Chua et al. 2013). For example, the availability of an oxygen-tolerant Clostridium strain capable of producing high amounts of butanol has been identified as the key to successful ABE fermentation. Several studies have demonstrated that cellular growth and DNA synthesis of $C$. acetobutylicum could be greatly suppressed in the presence of oxygen due to the organism's anaerobic nature (Aboulnaga et al. 2013). However, unlike many of the Clostridium strains used for ABE fermentation, C. acetobutylicum YM1 was found to be able to produce butanol efficiently in weak anaerobic conditions achieved by gas-flushing with oxygen-free nitrogen (Al-Shorgani, et al. 2015; Al-Shorgani et al. 2016). In this study, a basic trial to evaluate the production of butanol in batch culture and repeated-batch $\mathrm{ABE}$ fermentation was investigated by a local isolate of $C$. acetobutylicum YM1 from glucose as a carbon source.

\section{METHODOLOGY}

\section{MEDIUM PREPARATION}

Pre-culture was prepared using the tryptone-yeast extractacetate (TYA) medium. TYA medium was also used to prepare the inoculum and was the primary medium in several tests. To prepare the medium, $1 \mathrm{~L}$ of distilled water was used to dissolve $30 \mathrm{~g}$ glucose, $2 \mathrm{~g}$ yeast extract, $6 \mathrm{~g}$ tryptone, $3 \mathrm{~g}$ $\mathrm{CH}_{3} \mathrm{COONH}_{4}, 0.3 \mathrm{~g} \mathrm{MgSO}_{4} .7 \mathrm{H}_{2} \mathrm{O}, 0.5 \mathrm{~g} \mathrm{KH}_{2} \mathrm{PO}_{4}$ and $10 \mathrm{mg}$ $\mathrm{FeSO}_{4} .7 \mathrm{H}_{2} \mathrm{O}$. The $\mathrm{pH}$ of medium was set at $6.0 \pm 0.2$ using 1 $\mathrm{M} \mathrm{NaOH}$ and $1 \mathrm{M} \mathrm{HCl}$. The medium was autoclaved at $121^{\circ} \mathrm{C}$ for $15 \mathrm{~min}$ before use. 
TYA medium was used to prepare the inoculum of C. acetobutylicum YM1. Microbial inoculum was prepared by transferring $1 \mathrm{~mL}$ of the spore suspension of $C$. acetobutylicum YM1 into $9 \mathrm{~mL}$ of TYA medium, which was then heated for $1 \mathrm{~min}$ in boiling water, then cooled in iced water, and incubated for 1 to 2 days at $30^{\circ} \mathrm{C}$ under anaerobic condition. This culture was then subcultured in TYA medium and incubated for $18 \mathrm{~h}$ to be used as a fresh inoculum source.

\section{BATCH FERMENTATION SYSTEM}

In the present study, $C$. acetobutylicum YM1 was cultivated and grown using TYA medium containing $30 \mathrm{~g} / \mathrm{L}$ of glucose. The following growth conditions were applied; inoculum size of $10 \%(\mathrm{v} / \mathrm{v})$; incubation temperature of $30^{\circ} \mathrm{C}$ and the initial $\mathrm{pH}$ value was set at 6.2. Fermentation tests were conducted using a $250 \mathrm{~mL}$ Scott Duran bottles with a working volume of $100 \mathrm{~mL}$.

\section{REPEATED BATCH FERMENTATION SYSTEM}

The repeated-batch fermentation was conducted using 250 $\mathrm{mL}$ Duran bottle with a working volume of $100 \mathrm{~mL}$. TYA was used as a fermentation medium and the fermentation conditions were similar to that carried out in the batch fermentation. After the level of present glucose decreased in the broth to a predefined point, the subsequent batch was started by removing certain of the operational volume, fermented broth and promptly replacing that with a fresh TYA medium. This procedure is known as the fill and drain technique (Anastassiadis \& Rehm 2006).

\section{SOLVENTS AND ACIDS ANALYSIS}

Solvents (acetone, butanol and ethanol) and acids (butyric acid and acetic acid) were identified using gas chromatography system (Agilent Technologies, CA, USA) with a flame ionization detector (FID). An Equity-1 30-m capillary column $(30 \mathrm{~m} \times 0.32 \mathrm{~mm} \times 1.0 \mu \mathrm{m})$ was used (Supelco Co., PA, USA). An initial oven temperature of $40^{\circ} \mathrm{C}$ was gradually raised to $130^{\circ} \mathrm{C}$ at a rate of $8^{\circ} \mathrm{C} / \mathrm{min}$. Injector and detector settings were $250^{\circ} \mathrm{C}$ and $280^{\circ} \mathrm{C}$, respectively. Helium served as the carrier gas and was introduced into the column at $1.5 \mathrm{~mL} / \mathrm{min}$.

\section{GLUCOSE ASSAY BY 3, 5 DINITROSALICYLIC ACID METHOD}

Glucose concentration in the medium was determined using 3,5 dinitrosalicylic acid (DNS) method (Papanikolaou et al. 2008). To perform the measurement, $1 \mathrm{~mL}$ and $2 \mathrm{~mL}$ of the sample and DNS reagent solution were transferred to a test tube and kept inside boiling water for a period of $10 \mathrm{~min}$. The mixture containing reagents was left for cooling, than $7 \mathrm{~mL}$ of distillated water was added and absorbencies was read at $540 \mathrm{~nm}$ using spectrophotometer. The absorbencies at $540 \mathrm{~nm}$ for all samples were recorded and the glucose concentration was calculated from a standard curve.
The acidity/alkalinity of the medium was measured by a $\mathrm{pH}$ meter (Metrohm, Switzerland). Prior to sample measurement, $\mathrm{pH}$ buffers standard solution of $\mathrm{pH} 4$ and $\mathrm{pH} 7$ were employed for $\mathrm{pH}$ meter calibration.

\section{DETERMINATION OF CELL GROWTH}

Cell growth of $C$. acetobutylicum YM1 in TYA medium was determined by measuring the optical density at $600 \mathrm{~nm}$ using a Genesys 10 Scanning UV-VIS Spectrophotometer (Thermo Spectronic, Rochester, USA).

\section{RESULTS AND DISCUSSION}

\section{EFFECT OF DRAIN AND FILL VOLUME (DFV) ON BUTANOL FERMENTATION IN REPEATED-BATCH CULTURE}

In this study, the effect of drain and fill volume (DFV) on butanol production in repeated batch fermentation was investigated. Different DFV of $25 \%, 50 \%$, and $75 \%$ were examined. The volume of culture removed was replaced immediately with same amount of fresh TYA medium. It displays the $\mathrm{pH}$ level of $25 \%$ DFV in repeated batch cultures. The fermentation time taken by the first batch was $50 \mathrm{~h}$ and in subsequent batches the time taken was reduced to $48 \mathrm{~h}$; a stationary phase was observed at $48 \mathrm{~h}$. Repeated batch fermentation was carried out 5 times. The initial $\mathrm{pH}$ level of the first batch was 5.89 after inoculation while in the repeated batch 5 was decreased to 4.95 . It was noticed that the repeated batch 1 to 5 had a final $\mathrm{pH}$ reading ranging from 5.13 to 5 at the beginning of each run. However, the final $\mathrm{pH}$ readings had decreased steadily from 4.87 at the end of run 1 to 4.42 at the end of run 5 . The accumulation of acetic acid and butyric acid in the remaining medium of batches 1 to 5 had caused the decrease in readings of $\mathrm{pH}$.

In the first batch culture, the $C$. acetobutylicum YM1 cell growth in TYA medium displayed an increase in the growth reading (OD at $600 \mathrm{~nm}$ ) from 0.2 at $0 \mathrm{~h}$ to 2.24 towards the end of the first batch. The results obtained revealed that the cell division was started rapidly in the repeated-batch 1 to 5 and the growth in batches 1 to 5 was ranged from 2.22, 2.11, $2.03,1.69$ and 1.62, respectively, at the initial stage of each batch run. No significant lag phase was noticed in the repeated batch 1 to 5 . At the end of the test, the bacterial growth was reduced from 1.83 at run 1 to 1.19 at the end of run 5 . Similar results had also been obtained by Ariyajarearnwong et al. (2011) who stated that the viable cell concentrations in their study were lower in run 2 to 8 than in that observed in repeated batch run 1 .

The initial glucose concentration was $30 \mathrm{~g} / \mathrm{L}$ and decreased to $7.62 \mathrm{~g} / \mathrm{L}$ in the end of batch culture. Additional reductions were observed in repeated-batch 1 to 5 with concentrations of $7.62,1.76,1.42,3.19,3.62$, and $8.76 \mathrm{~g} / \mathrm{L}$, respectively, as shown in Figure 1a. The butanol concentration were reduced by increasing the repeated batch cycles which 
ranged in batch 1 to 5 from 4.17, 2.81, 2.36, 2.25 and 1.40 $\mathrm{g} / \mathrm{L}$, respectively, and might be caused by lower glucose concentration in the broth of these batches compared to earlier concentrations of the first batch (Figure 1a). For batch 1, the initial glucose concentration in the fermentation broth was $30 \mathrm{~g} / \mathrm{L}$ and at the end, the concentration of butanol reached $4.17 \mathrm{~g} / \mathrm{L}$. Overall, the maximum concentration of butanol in the fermentation DFV of $25 \%$ in repeated-batch 1 was 4.17 $\mathrm{g} / \mathrm{L}$ at $300 \mathrm{~h}$ (Figure 1a). Al-Shorgani et al. (2014) had stated that the initial glucose concentration would highly influence butanol production.

In $50 \%$ DFV experiment, the culture medium for the repeated-batch was replaced immediately with the same volume of fresh TYA medium. The initial $\mathrm{pH}$ reading of batch 1 after inoculation was 5.89 which decreased to 4.91 at the end of this cycle. In the repeated batch 1 to $5, \mathrm{pH}$ ranged from 5.12 to 5.03 at the start of each run. Additionally, the final $\mathrm{pH}$ reading had continuously declined from 4.85 at the end of run 1 to 4.28 at the end of run 5 . The continuous reduction in batch 1 to 5 was caused by the accumulation of acids in the remaining medium.

In batch culture, the growth of $C$. acetobutylicum YM1 in TYA medium culture was accelerated by the increase in reading (OD $600 \mathrm{~nm}$ ) from 0.2 after inoculation to 2.24 at the end. The repeated batches 1 to 5 was anticipated to divide rapidly after inoculation with OD readings ranging from 2.19 to 1.27 . There was no significant lag phase at the beginning of each subsequent batch. The reduction was higher in 50\% DFV compared to $25 \%$ DFV because of the increase in the volume of replacing medium which recorded as 1.12 at run 2 and 0.67 at the end of run 5. Dashti and Abdeshahian (2016) had stated that the highest level of the biomass concentration had been obtained during the first cycle of the repeated batch culture, which indicated that an increase in the number of repeated batch cycles had an adverse influence on biomass concentration and microbial cell growth.

In repeated batch cycle 1 , the initial glucose concentration of $30 \mathrm{~g} / \mathrm{L}$ was reduced to $7.68 \mathrm{~g} / \mathrm{L}$ in the end. In repeated batches 1 to 5 , the concentrations of glucose were reduced at the end to $7.10,9.56,8.77,10.71$ and $15.71 \mathrm{~g} / \mathrm{L}$, respectively, as shown in Figure 1b. In addition, in repeated batches 1 to 5, the butanol concentrations obtained were ranged from 5.12 to $1.07 \mathrm{~g} / \mathrm{L}$ as shown in Figure 1b. This gradual decrease of butanol concentration might be caused by the low glucose concentration in the culture. Total fermentation time of five successive repeated batches that kept for $300 \mathrm{~h}$ at $50 \% \mathrm{DFV}$ had the maximum concentration of butanol of $5.12 \mathrm{~g} / \mathrm{L}$ (Figure 1b).

In the $75 \%$ DFV experiment, it was noticed that the changes are not similar with $50 \%$ DFV and $25 \%$ DFV. For batch 1 , the initial $\mathrm{pH}$ was 5.89 which dropped to 5.03 at the end. Thereafter the $\mathrm{pH}$ values of the repeated batches 1 to 5 at the beginning of the batch varied from 5.38, 5.2, 5.23 and 5.29 , respectively. The $\mathrm{pH}$ readings at the end had decreased continuously and the reading for run 1 was 4.88 and 4.62 for run 5 . The continuous decline was caused by accumulated acetic acid and butyric acid in the remaining medium of repeated batch cycle 1 to cycle 5 .
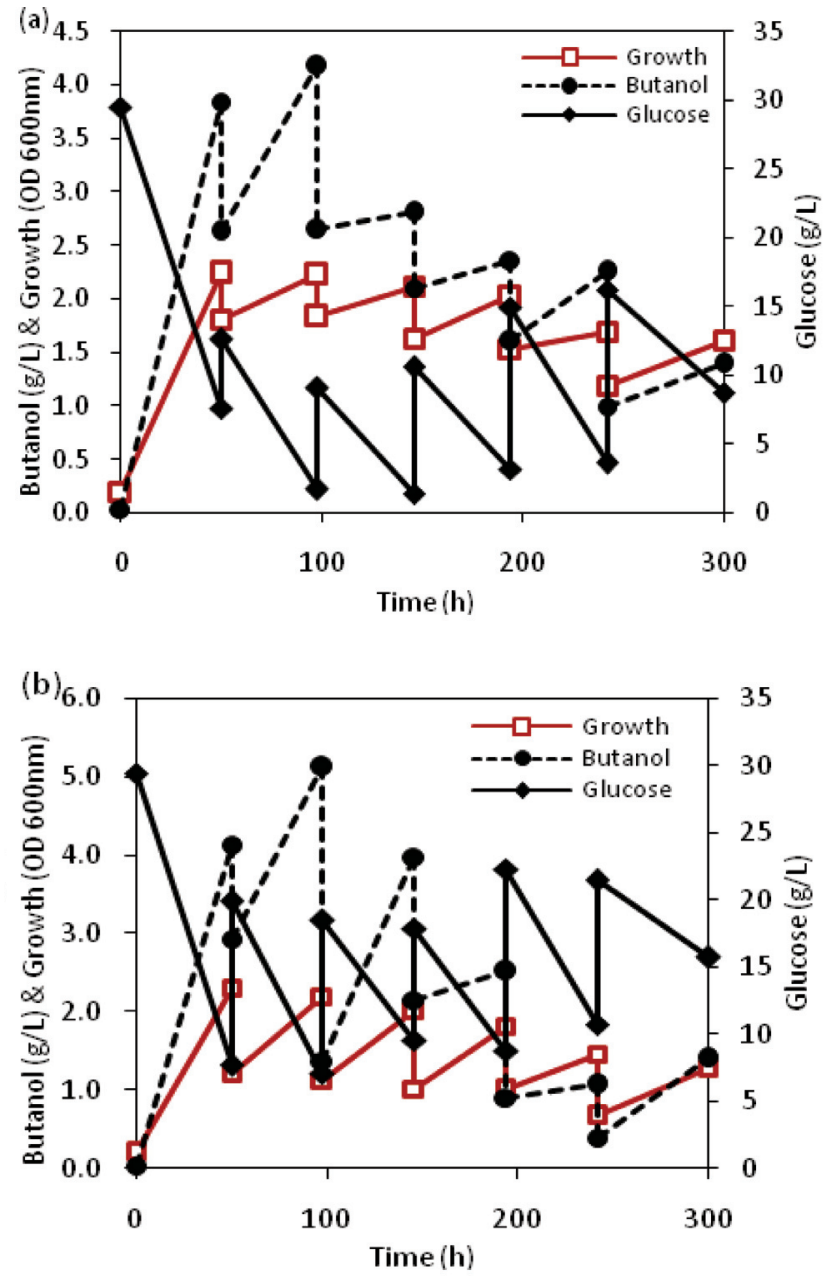

(c)

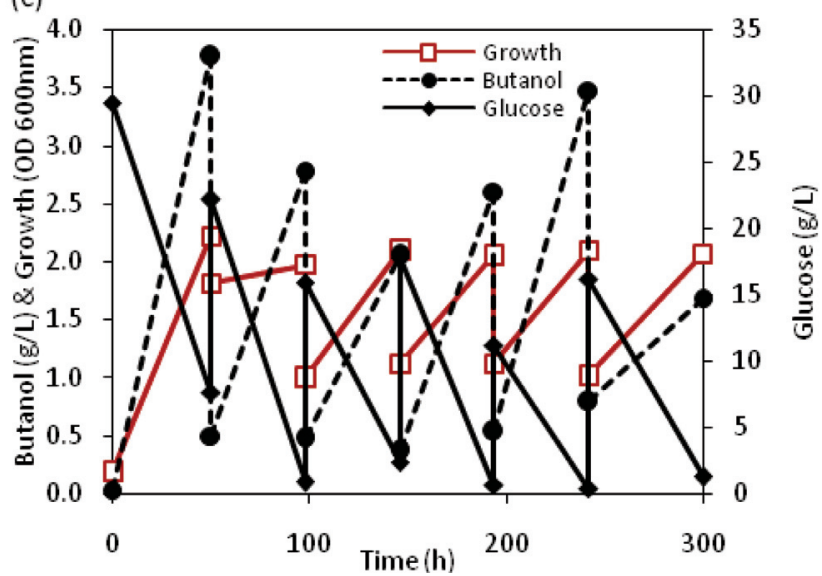

FIGURE 1. Profiles of bacterial growth, glucose concentration and butanol production in repeated batch culture by $C$. acetobutylicum YM1 at: (a) $25 \% \mathrm{DFV}$, (b) $50 \%$ DFV and (c) $75 \%$ DFV

In batch culture 1 of $75 \% \mathrm{DFV}$, the $C$. acetobutylicum YM1 cell growth in TYA medium was measured by the rise in the OD at $600 \mathrm{~nm}$ which increased from 0.2 at $0 \mathrm{~h}$ to 2.24 at the end. The oD readings ranging from 1.97, 2.1, 2.06, 2.09 and 2.07 were observed at the initial stage of each run in the repeated batches 1 to 5 , respectively. No obvious lag phase 
was noticed. In repeated batch 1 , a decrease in cell growth was recorded as $1.01 \mathrm{OD}$ and in run 5 recorded $1.02 \mathrm{OD}$ at the end of the run which indicated a stable decrease in cell growth along with the increase in the repeated batch cycle runs.

The results obtained from this study for $25 \%$ and $50 \%$ DFV are supported by Choi et al. (2009) who noted that a higher DFV of $20 \%$ produced higher cell concentration and final product compared to lower DFV of $10 \%$ and $5 \%$. In contrast, Ariyajarearnwong et al. (2011) found that an increase in DFV from $50 \%$ to $75 \%$ produced an increase in the final product concentration and productivity.

In the repeated batch cycles 1 to 5 , glucose concentrations had a reduction of $0.89,2.36,0.67,0.38$ and $1.29 \mathrm{~g} / \mathrm{L}$, respectively, as shown in Figure 1c. In repeated batches 1 to 5 , butanol concentration concentrations were $2.78,2.05$, $2.60,3.47$ and $1.688 \mathrm{~g} / \mathrm{L}$, respectively (Figure 1c) and this reduction was caused by lower glucose concentration in the broth. The comparison between all DFV volumes is illustrated in Table 1. The total fermentation time taken for testing five successive repeated batches at $75 \%$ DFV was $300 \mathrm{~h}$ and the maximum butanol concentration as $3.4 \mathrm{~g} / \mathrm{L}$ was obtained in repeated batch cycle 4 .

TABLE 1. Effect of DFV on butanol fermentation in repeated batch culture of C. acetobutylicum YM1

\begin{tabular}{lccc}
\hline \multirow{2}{*}{ Parameters } & \multicolumn{3}{c}{ DFV (\%) } \\
\cline { 2 - 4 } & 25 & 50 & 75 \\
\hline Growth (OD $\left.{ }_{600 \mathrm{~nm}}\right)$ & 2.22 & 2.20 & 2.09 \\
Acetone (g/L) & 1.84 & 2.24 & 1.89 \\
Butanol (g/L) & 4.17 & 5.12 & 3.47 \\
Ethanol (g/L) & 0.39 & 0.43 & 0.15 \\
ABE (g/L) & 6.41 & 7.78 & 5.50 \\
Butyric acid (g/L) & 0.52 & 0.73 & 1.90 \\
Acetic acid (g/L) & 0.36 & 0.24 & 0.65 \\
Butanol yield (g/g) & 0.38 & 0.44 & 0.32 \\
Residual glucose $(\mathrm{g} / \mathrm{L})$ & 1.77 & 7.10 & 0.38 \\
Repeated batch cycle & 1 & 1 & 4 \\
\hline
\end{tabular}

In terms of yield and productivity, the productivity and yield of butanol, the concentration of the by-products are depended on the glucose utilized and the DFV of replaced fresh medium. A significant difference in the production of the final butanol concentration was observed at the end of every batch. The maximum titer of butanol in $25 \%$ DFV was obtained in repeated batch $1(4.17 \mathrm{~g} / \mathrm{L})$, while for $50 \%$ was in repeated batch $1(5.12 \mathrm{~g} / \mathrm{L})$ and for $75 \%$ was in repeated batch culture $4(3.4 \mathrm{~g} / \mathrm{L})$ as shown in Table 1 . The maximum butanol productivity for $25 \%$ DFV was in repeated batch 1 as $0.08 \mathrm{~g} / \mathrm{L} . \mathrm{h}$, while at DFV of $50 \%$ in repeated batch 1 , the productivity was $0.11 \mathrm{~g} / \mathrm{L} . \mathrm{h}$ and at a DFV of $75 \%$ the productivity was $0.08 \mathrm{~g} / \mathrm{L} . \mathrm{h}$ (Table 1 ). The maximum butanol yield for $25 \%$ DFV was in repeated batch 1 was $0.38 \mathrm{~g}$ butanol/ g glucose, while repeated batch 1 in DFV of $50 \%$ yielded a high yield of $0.44 \mathrm{~g}$ butanol $/ \mathrm{g}$ glucose and at repeated batch 4 of $75 \%$ DFV the yield was decreased to $0.32 \mathrm{~g}$ butanol $/ \mathrm{g}$ glucose (Table 1).
Maximum concentration of AEB in $25 \%$ DFV was observed in repeated batch 1 as $6.41 \mathrm{~g} / \mathrm{L}$. In repeated batch 1 at $50 \% \mathrm{DFV}$, the ABE concentration was $7.79 \mathrm{~g} / \mathrm{L}$ and 5.51 $\mathrm{g} / \mathrm{L}$ of $\mathrm{ABE}$ was produced in repeated batch 4 of $75 \% \mathrm{DFV}$. The maximum productivity of ABE for $25 \% \mathrm{DFV}$ was recorded in repeated batch 1 as $0.13 \mathrm{~g} / \mathrm{L} . \mathrm{h}$ and the highest butanol productivity of $0.11 \mathrm{~g} / \mathrm{L}$.h was found from repeated batch 1 of $50 \%$ DFV while the culture of $75 \%$ DFV produced $0.51 \mathrm{~g} / \mathrm{L} . \mathrm{h}$ as the highest in the repeated batch 4 . In repeated batch 1 of $25 \% \mathrm{DFV}$, the maximum ABE yield was $0.59 \mathrm{~g} \mathrm{ABE} / \mathrm{g}$ glucose. With $50 \% \mathrm{DFV}$, the repeated batch 2 yielded $0.66 \mathrm{~g} \mathrm{ABE} / \mathrm{g}$ glucose. Whereas, at $75 \%$ DFV in repeated batch 4 , the yield dropped to $0.51 \mathrm{~g} \mathrm{ABE} / \mathrm{g}$ glucose.

EFFECT OF DRAIN AND FILL TIME (DFT) ON BUTANOL PRODUCTION IN REPEATED BATCH FERMENTATION

The effect of time addition of medium as a drain and fill volume (DFT) was studied. The DFV was kept constant at 50\% and the time of addition (DFT) was changed for every 12,24 , 36 and $48 \mathrm{~h}$ intervals during repeated batch fermentation to verify the best time for the production of butanol.

Repeated batch culture at $50 \%$ DFV was tested at every $12 \mathrm{~h}$ for 5 runs and in repeated batch cycle 1 , the initial $\mathrm{pH}$ was 5.89 which decreased to 5.28 at the end. The readings obtained for repeated batches 1 to 5 showed that the $\mathrm{pH}$ values were 5.52, 5.09, 5.06, 5.14 and 5.20, respectively, at the start of each run. In runs 1 to 5 , the $\mathrm{pH}$ values were quite stable with readings ranging from 4.87, 4.77, 4.86, 4.95 and 4.86 at the end of the runs. In batch 1, the growth of C. acetobutylicum YM1 culture was increased from 0.2 OD at $0 \mathrm{~h}$ to 1.45 at the end. In the repeated batches 1 to 5 , the cells divided rapidly after inoculation with the OD ranging from 1.04 to 1.66 at the initial stage of each run. At the end of run 5 there was only a slight increase from 2.104 (run 1) to 2.256 in run 5 . The initial glucose concentration in the batch culture was $30 \mathrm{~g} / \mathrm{L}$ which was higher than in the repeated batches which varied from 26.54, 23.80, 21.08, 18.21 and $21.27 \mathrm{~g} / \mathrm{L}$, respectively. In repeated batches 1 to 5 , the final remaining glucose concentrations were $16.17,10.51,9.72$, 12.78 and $10.41 \mathrm{~g} / \mathrm{L}$, respectively.

In DFT of $24 \mathrm{~h}$, in repeated batch 1 , the $\mathrm{pH}$ at the beginning was 5.89 and dropped to 4.78 at the end of the batch run. At the beginning of repeated batches 1 to 5 , the readings of $\mathrm{pH}$ ranged from 5.04 to 5.12 but at the end of run 5 , the $\mathrm{pH}$ continued to fall to 4.73 . In batch culture 1, the growth of C. acetobutylicum YM1 increased from 0.2 after inoculation $(0 \mathrm{~h})$ to 2.25 at the end. In repeated batches 1 to 5 , the bacterial cell growth was measured as 1.91, 2, 2.01, 2.21, and 1.99 OD, respectively, at the initial stage of each run. At the end of run 5 , the bacteria growth was 2.39 oD compared to 2.23 oD in the first batch. The initial glucose concentration of the batch culture was $30 \mathrm{~g} / \mathrm{L}$ and it was higher than that measured in the repeated batches which found as $24.79,16.48,18.52,15.77$ and $17.47 \mathrm{~g} / \mathrm{L}$, respectively. At the end of the experiment, the remaining glucose concentrations in repeated batches 1 to 5 were $7.46,8.10,1.74,2.98$ and $6.85 \mathrm{~g} / \mathrm{L}$, respectively. 
The highest concentration of butanol produced was $4.56 \mathrm{~g} / \mathrm{L}$ in this experiment.

Increasing the DFT to $36 \mathrm{~h}$ was also investigated. The $\mathrm{pH}$ in repeated batch cultures readings ranged from 5.23, 5.26, 5.13, 5.08 and 5.11, respectively, at the beginning of runs 1 to 5. Growth of $C$. acetobutylicum YM1 at DFT of $36 \mathrm{~h}$ was slightly reduced in the repeated batch (run 5) as 1.99 OD compared to $2.12 \mathrm{OD}$ in the first repeated batch culture. At DFT of $36 \mathrm{~h}$, the glucose concentrations were found as 26.421, $17.64,14.25,18.49$ and $22.23 \mathrm{~g} / \mathrm{L}$ in repeated batches 1 to 5 , respectively. At the end of the experiment, the remaining glucose concentrations for repeated batches 1 to 5 were 2.97, $2.03,1.85,7.19$ and $1.87 \mathrm{~g} / \mathrm{L}$, respectively. The maximum butanol concentration of $2.33 \mathrm{~g} / \mathrm{L}$ was obtained in repeated batch 2 .

TABLE 2. Effect of FDT on butanol fermentation in repeated batch culture of C. acetobutylicum YM1

\begin{tabular}{lrrrr}
\hline & \multicolumn{4}{c}{ Addition time (h) } \\
\cline { 2 - 5 } Parameters & \multicolumn{1}{c}{12} & \multicolumn{1}{c}{24} & \multicolumn{1}{c}{36} & \multicolumn{1}{c}{48} \\
\hline Repeated batch cycle & 5 & 4 & 2 & 1 \\
Max butanol (g/L) & 0.38 & 4.56 & 2.33 & 5.12 \\
ABE $(\mathrm{g} / \mathrm{L})$ & 0.83 & 7.27 & 3.62 & 7.78 \\
Butanol productivity (g/L.h) & 0.03 & 0.19 & 0.06 & 0.11 \\
ABE productivity $(\mathrm{g} / \mathrm{L} . \mathrm{h})$ & 0.07 & 0.30 & 0.10 & 0.16 \\
Initial glucose $(\mathrm{g} / \mathrm{L})$ & 21.27 & 15.78 & 17.64 & 18.73 \\
Residual glucose $(\mathrm{g} / \mathrm{L})$ & 10.41 & 2.98 & 2.04 & 7.10 \\
Utilized glucose $(\mathrm{g} / \mathrm{L})$ & 10.86 & 12.80 & 15.60 & 11.63 \\
Butanol yield $(\mathrm{g} / \mathrm{g})$ & 0.03 & 0.36 & 0.15 & 0.44 \\
ABE yield $(\mathrm{g} / \mathrm{g})$ & 0.08 & 0.57 & 0.23 & 0.67 \\
& & & & \\
\hline
\end{tabular}

Increasing the DFT to $48 \mathrm{~h}$ showed a better butanol fermentation performance in repeated batch fermentation. C. acetobutylicum YM1 cell growth in at the beginning of each run was $1.21,1.12,1.01,1.0$, and 0.67 in repeated batches 1 to 5 , respectively. While the growth at the end of repeated batch runs 1 to 5 were ranged from $2.19,2.02,1.82$, 1.46 , and $1.28 \mathrm{OD}$, respectively. Concentrations of glucose in repeated batches 1 to 5 were 18.73, 18.49, 17.88, 22.32, and $21.43 \mathrm{~g} / \mathrm{L}$, respectively. At the end of each repeated batch run, the glucose concentrations were 7.10, 9.56, 8.77, 10.71 and $15.71 \mathrm{~g} / \mathrm{L}$, respectively. The maximum butanol concentration was $5.12 \mathrm{~g} / \mathrm{L}$ in repeated batch 1 with a yield of $0.44 \mathrm{~g} / \mathrm{g}$ (Table 2). Results in this study exhibited that increasing the time of drain and fill from $12 \mathrm{~h}$ to $48 \mathrm{~h}$ led to enhance butanol production, productivity and yield. This is in agreement with a study reported by Dashti and Abdeshahian (2016) who found that increasing the time from $12 \mathrm{~h}$ to 48 $\mathrm{h}$ created a progressive increase in the production of lipid which indicated the positive influence of increasing the time on the metabolic activity of Cunninghamella bainieri $2 \mathrm{~A} 1$ in the fermentation for lipid production.

Table 2 summarized the butanol production, yield and productivities for butanol and total $\mathrm{ABE}$ at different times of DFT. It can be seen that at DFT of $48 \mathrm{~h}$, the butanol concentration was the maximum as $5.12 \mathrm{~g} / \mathrm{L}$ with $\mathrm{ABE}$ concentration of $7.78 \mathrm{~g} / \mathrm{L}$ at the first repeated batch culture. DFT at $48 \mathrm{~h}$ also resulted in high yield of butanol as $0.44 \mathrm{~g} / \mathrm{g}$ and ABE yield of $0.67 \mathrm{~g} / \mathrm{g}$. Moreover, in repeated batch cycle 2 of DFT $48 \mathrm{~h}$, the yield of butanol was improved to $0.45 \mathrm{~g} / \mathrm{g}$ while the butanol concentration was lower $(3.97 \mathrm{~g} / \mathrm{L})$.

In the control batch culture, the maximum concentration of butanol was $3.78 \mathrm{~g} / \mathrm{L}$, the maximum butanol productivity was $0.08 \mathrm{~g} / \mathrm{L} . \mathrm{h}$, and the butanol yield was $0.15 \mathrm{~g} / \mathrm{g}$ when glucose concentration of $30 \mathrm{~g} / \mathrm{L}$ was used. During the fermentation of glucose in TYA medium for $72 \mathrm{~h}$, the solvent production started at $20 \mathrm{~h}$ and continued increasing to reach the maximum concentrations of solvent and butanol at 46 h.

COMPARISON OF BATCH AND REPEATED BATCH FERMENTATION FOR BUTANOL PRODUCTION

The productivity and yield of butanol in repeated batch culture and the concentration of by-products were dependent on the glucose concentration used. The best conditions for repeated batch was with DFV of $50 \%$ at replacement time of $48 \mathrm{~h}$. There was a significant difference in the level of the final butanol concentrations at the end of every repeated batch. The maximum concentration of butanol in repeated batch culture for $50 \%$ every $48 \mathrm{~h}$ was in repeated batch cycle 1 as $5.12 \mathrm{~g} / \mathrm{L}$ and the butanol productivity was $0.11 \mathrm{~g} / \mathrm{L}$.h with a butanol yield of $0.44 \mathrm{~g} / \mathrm{g}$.

Repeated batch fermentation and fed-batch fermentation modes are the most suitable fermentation processes compared to the batch or continuous fermentation processes because it can improve the production of butanol and solvents and decrease the residual substrate. Fed-batch fermentation also is applied to avoid the substrate inhibition or occurring of catabolite repression ( $\mathrm{Li}$ et al. 2011). In this study, the results showed that repeated batch fermentation produced high titer of butanol and total solvents and the yield and productivity were maximized over than batch fermentation. Similar finding was reported by Dolejs et al. (2014) who found that the highest productivity of butanol and solvents were achieved when the repeated batch fermentation was used compared to fed-batch fermentation.

Recently, Liu et al. (2018) reported that using repeated batch culture system produced highest concentration of solvent and butanol compared to that obtained from batch culture fermentation. They found that the maximum butanol of $4.9 \mathrm{~g} / \mathrm{L}$ butanol was obtained with a total solvent yield of $0.41 \mathrm{~g} / \mathrm{g}$ in repeated-batch fermentation in the FBB system using immobilized $C$. beijerinckii NCIMB 8052 (Li et al. 2018). Our study is in agreement with that reported by Liu et al (2018), while the butanol titer that obtained in our study was higher $(5.12 \mathrm{~g} / \mathrm{L})$ with a higher butanol and total solvent yield in repeated batch fermentation of C. acetobutylicum YM1.

During the repeated batch culture fermentation, residual acids concentrations (acetic acid and butyric acid) were left which affect the following repeated batch culture. The presence of these acids in the culture are essential to shift the fermentation from the acidogenic phase to the 
solventogenic phase and resulted in improved solvent and butanol fermentation. The presence of enough inoculum in $50 \%$ DFV with residual acids led to eliminate the lag phase of bacterial growth and immediate butanol production then consequently improved the productivity and yield of butanol and $\mathrm{ABE}$ in repeated batch fermentation process.

\section{CONCLUSION}

The present work was a basic trial to evaluate the C. acetobutylicum YM1 to produce butanol in batch and repeated batch $\mathrm{ABE}$ fermentation. In batch fermentation, the maximum butanol production was $3.7 \mathrm{~g} / \mathrm{L}$ with a productivity of $0.0824 \mathrm{~g} / \mathrm{L} . \mathrm{h}$ and the yield was $0.14 \mathrm{~g} / \mathrm{g}$. The effect of drain and fill volume (DFV) on the production of butanol from C. acetobutylicum YM1 in repeated batch fermentation was optimized using different volumes for $300 \mathrm{~h}$. The maximum production of butanol was $5.12 \mathrm{~g} / \mathrm{L}$ in $50 \%$ volume while in $75 \%$ the production of butanol decreased drastically to $3.71 \mathrm{~g} / \mathrm{L}$. The time of drain and fill in 50\% feeding strategy was also tested using different time: $12 \mathrm{~h}, 24 \mathrm{~h}, 36 \mathrm{~h}$ and $48 \mathrm{~h}$. The results showed that $48 \mathrm{~h}$ drain and fill time produced the highest concentration of butanol as $5.12 \mathrm{~g} / \mathrm{L}$, followed by $24 \mathrm{~h}$ drain and fill time which produced butanol concentration of $4.56 \mathrm{~g} / \mathrm{L}$. Repeated batch fermentation by C. acetobutylicum YM1 produced higher butanol concentration and yield compared to batch culture fermentation. Further studies are required to be achieved to improve the yield and productivity of butanol such as cells immobilization during repeated batch fermentation.

\section{ACKNOWLEDGEMENTS}

The authors wish to express their gratitude to the Universiti Kebangsaan Malaysia for financing this research work through grants: UKM-DIP-2017-019 and GUP-2016-06.

\section{REFERENCES}

Aboulnaga, E.-H., Pinkenburg, O., Schiffels, J., ElRefai, A., Buckel, W. \& Selmer, T. 2013. Effect of an oxygen-tolerant bifurcating Butyryl coenzyme A dehydrogenase/electron-transferring flavoprotein complex from Clostridium difficile on butyrate production in Escherichia coli. Journal of Bacteriology 195(16): 3704-3713.

Al-Shorgani, N. K. N., Kalil, M. S., Yusoff, W. M. W. \& Hamid, A. A. 2015. Biobutanol production by a new aerotolerant strain of Clostridium acetobutylicum YM1 under aerobic conditions. Fuel 158: 855-863.

Al-Shorgani, N. K. N., Isa, M. H. M., Yusoff, W. M. W., Kalil, M. S. \& Hamid, A. A. 2016. Isolation of a Clostridium acetobutylicum strain and characterization of its fermentation performance on agricultural wastes. Renewable Energy 86: 459-465.
Al-Shorgani, N. K. N., El Mubarak, T., Kalil, M. S. Yusoff, W. M. W. \& Hamid, A. A. 2014. Biobutanol production by a new local isolate of Clostridium acetobutylicum YM1. AIP Conference Proceedings, 1614(1): 523-527.

Al-Shorgani, N. K. N., Kalil, M. S. \& Yusoff, W. M. W. 2011. The effect of different carbon sources on biobutanol production using Clostridium saccharoperbutylacetonicum N1-4. Biotechnology 10(3): 280-285.

Anastassiadis, S. \& Rehm, H.-J. 2006. Citric acid production from glucose by yeast Candida oleophila ATCC 20177 under batch, continuous and repeated batch cultivation. Electronic Journal of Biotechnology 9(1): 26-39.

Ariyajarearnwong, P., Laopaiboon, L., Jaisil, P. \& Laopaiboon, P. 2011. Repeated-batch ethanol fermentation from sweet sorghum juice by free cells of Saccharomyces cerevisiae Np 01. African Journal of Biotechnology 10(63): 1390913918.

Bramono, S. E., Lam, Y. S., Ong, S. L. \& He, J. 2011 A mesophilic Clostridium species that produces butanol from monosaccharides and hydrogen from polysaccharides. Bioresource Technology 102(2): 95589563.

Chen, B.-Y., Chuang, F.-Y., Lin, C.-L. \& Chang, J.-S. 2012 Deciphering butanol inhibition to Clostridial species in acclimatized sludge for improving biobutanol production. Biochemical Engineering Journal 69: 100-105.

Choi, G. W., Kang, H. W., Moon, S. K. 2009. Repeated-batch fermentation using flocculent hybrid Saccharomyces cerevisiae CHFY0321 for efficient production of bioethanol. Applied Microbiolog and Biotechnolology 84: 261-269.

Chua, T. K., Liang, D.-W., Qi, C., Yang, K.-L. \& He, J. 2013. Characterization of a Butanol-acetone-producing Clostridium strain and identification of its solventogenic genes. Bioresource Technology 135: 372-378.

Dashti, M. G., \& Abdeshahian, P. 2016. Batch culture and repeated-batch culture of Cunninghamella bainieri 2A1 for lipid production as a comparative study. Saudi Journal of Biological Sciences 23(2): 172-180.

Dolejs, I., Krasnan, V., Stloukal, R., Rosenberg, M. \& Rebros, M. 2014. Butanol production by immobilised Clostridium acetobutylicum in repeated batch, fed-batch, and continuous modes of fermentation. Bioresource Technology 169: 723-730.

Lee, S. H., Ha, S. H. Hiep, N. M. Chang, W-J \& Koo, Y.M. 2008. Lipase-catalyzed synthesis of glucose fatty acid ester using ionic liquids mixtures. Journal of Biotechnology 133(4): 486-489.

Li, S.-Y., Srivastava, R., Suib, S.L., Li, Y. \& Parnas, R.S. 2011. Performance of batch, fedbatch, and continuous A-B-E fermentation with $\mathrm{pH}$-control. Bioresource Technology 102: 4241-4250.

Liu, J., Liu, Z. \& Guo, T. 2018. Repeated-batch fermentation by immobilization of Clostridium beijerinckii NCIMB 8052 in a fibrous bed bioreactor for ABE (acetone-butanol-ethanol) production. Journal of 
Renewable and Sustainable Energy 10(1). https://doi. org/10.1063/1.5007133.

Nuanpeng, S., Laopaiboon, L., Srinophakun, P., Klanrit, P., Jaisil, P. \& Laopaiboon, P. 2011. Ethanol production from sweet sorghum juice under very high gravity conditions: Batch, repeated-batch and scale up fermentation. Electronic Journal of Biotechnology 14(1): 4-5.

Papanikolaou, S., Galiotou-Panayotou, M. Fakas, S. Komaitis M. \& Aggelis, G. 2008. Citric acid production by Yarrowia lipolytica cultivated on olive-mill wastewaterbased media. Bioresource Technology 99(7): 2419. 2428.

Pfromm, P. H., Amanor-Boadu, V. R. Nelson, P., Vadlani \& Madl, R. 2010. Bio-butanol vs. bio-ethanol: a technical and economic assessment for corn and switchgrass fermented by yeast or Clostridium acetobutylicum. Biomass and Bioenergy 34(4): 515-524.

Qureshi, N. \& Blaschek, H. 2000. Butanol production using Clostridium beijerinckii BA101 hyper-butanol producing mutant strain and recovery by pervaporation. Applied Biochemistry and Biotechnology 84-86: 225-235.

$\mathrm{Xu}, \mathrm{M} .2014$. Comparative genomic analysis and metabolic engineering of Clostridium acetobutylicum for enhanced n-butanol tolerance and production. 2014. PhD Thesis. The Ohio State University, USA.

Yazdani, S. S. \& Gonzalez, R. 2007. Anaerobic fermentation of glycerol: a path to economic viability for the biofuels industry. Current Opinions in Biotechnology 18(3): 213-219.
*Mohd Sahaid Kalil

Research Centre for Sustainable Process Technology (CESPRO),

Chemical Engineering Programme,

Faculty of Engineering and Built Environment,

Universiti Kebangsaan Malaysia,

43600 UKM Bangi, Malaysia.

Khadeja Khalifa Khalifa, Abdualati Ibrahim Al-Tabib, Research Centre for Sustainable Process Technology (CESPRO),

Faculty of Engineering and Built Environment,

Universiti Kebangsaan Malaysia,

43600 UKM Bangi, Malaysia.

Najeeb Kaid Nasser Al-Shorgani

Department of Applied Microbiology,

Faculty of Applied Sciences, Taiz University,

Taiz, Yemen

*Corresponding author; email: sahaid@ukm.edu.my

Received date: $9^{\text {th }}$ May 2018

Accepted date: $7^{\text {th }}$ August 2018

Online First date: $1^{\text {st }}$ October 2018

Published date: $30^{\text {th }}$ November 2018 